\title{
Klimat akustyczny polskich uzdrowisk The acoustic climate of Polish health resorts
}

\author{
Jarosław Baranowski \\ Instytut Geografii i Przestrzennego Zagospodarowania im. S. Leszczyckiego PAN \\ ul. Twarda 51/55, 00-818 Warszawa \\ j.bar@twarda.pan.pl
}

Zarys treści. Celem badań była ogólna ocena stanu zagrożenia hałasem w uzdrowiskach polskich i trendu ich zmian w ostatnich 10 latach. W większości badanych uzdrowisk miejsca najbardziej narażone na nadmierny hałas, charakteryzowały się przekroczeniem dopuszczalnych normy. Jednocześnie, w każdym z nich znajdowały się obszary względnie ciche, gdzie normy hałasu były zachowane. Istotnym elementem opracowania było również wskazanie, jakie czynniki stanowią realne źródło hałasu i jakie działania naprawcze przynoszą oczekiwane efekty (studium przypadku: uzdrowiska Świnoujście i Kołobrzeg). Badania natężenia ruchu w obu uzdrowiskach wskazują na znaczący jego udział w strukturze klimatu akustycznego. Zwrócono uwagę na funkcje, jakie pełnią w dzisiejszych czasach uzdrowiska, gdyż rozszerzenie ich oferty prowadzi do przekształcenia w obiekty wielofunkcyjne. Powiązania działalności sanatoryjnej i turystycznej wyznaczają nową jakość w polskich uzdrowiskach, ich wielofunkcyjność wiąże się ze zwiększoną liczbą osób odwiedzających oraz z pogorszeniem warunków akustycznych w środowisku.

Słowa kluczowe: hałas, klimat akustyczny, uzdrowiska statutowe, klimatoterapia.

\begin{abstract}
Wstęp
Wpływ hałasu na zdrowie człowieka

Troska o ciszę i sprzyjający klimat akustyczny w środowisku życia człowieka powinna dotyczyć każdego miejsca, w którym przebywa (dom, miejsce pracy i wypoczynku, ulice miast, środki transportu itd.). W sposób szczególny powinno to objąć uzdrowiska. Polsce istnieje 45 uzdrowisk statutowych zlokalizowanych na obszarze 13 województw, przy czym najwięcej ich znajduje się w województwie dolnośląskim - 11 i małopolskim - 10, pojedyncze zaś znajdują się w woj. warmińsko-mazurskim, mazowieckim i łódzkim. Oprócz uzdrowisk na liście Ministerstwa Zdrowia siedem miejscowości posiada status obszaru ochrony uzdrowiskowej. Chorzy przyjeżdżający do uzdrowiska z wielkomiejskich aglomeracji powinni mieć warunki do leczenia i wypoczynku w cichym środowisku, zwłaszcza, że zabiegi klimatoterapeutyczne (aeroterapia, helioterapia, terenoterapia) są prowadzone w terenie otwartym. W uzdrowiskach, obok wód leczniczych i peloidów, niezbędne są korzystne warunki klimatyczne o właściwościach leczniczych i profilaktycznych. Poza odpowiednimi cechami klimatu (temperatura, usłonecznienie, opady, wiatr, wilgotność powietrza) składają się na nie także warunki aerosanitarne i akustyczne (Kuchcik i inni, 2013; Błażejczyk i Kuchcik, 2017).
\end{abstract}


Pod pojęciem klimatu akustycznego rozumie się czasowe i przestrzenne zróżnicowanie bodźców akustycznych w środowisku. Związane są one z różnym ciśnieniem akustycznym powietrza, powstałym w wyniku wzbudzenia drgań mechanicznych (fal dźwiękowych) działających za pośrednictwem powietrza na narząd słuchu i inne organy organizmu człowieka (Augustyńska i inni, 2014).

Hałas jest jednym z czynników środowiskowych negatywnie wpływających na komfort życia człowieka. Czym jest hałas? Można go określić jako niepożądany, nieprzyjemny, dokuczliwy lub szkodliwy dźwięk o dowolnym charakterze akustycznym. W Encyklopedii PWN hałas definiowany jest jako „dźwięk niepożądany, którego działanie może być uciążliwe lub szkodliwe dla człowieka”. Granica uciążliwości hałasu jest płynna i zależna nie tylko od rodzaju słyszanych zakłóceń, ale również od odporności nerwowo-psychicznej człowieka, jego chwilowego nastroju lub rodzaju wykonywanej pracy. Generalnie, długotrwała ekspozycja na zbyt głośne dźwięki wpływa negatywnie na zdrowie człowieka (Babisch i inni, 2003; WHO, 2009, 2011).

Podobnie jak w przypadku innych rodzajów zagrożeń występujących w środowisku życia człowieka, hałas może oddziaływać w sposób ciągły lub okresowy i mieć różną intensywność. Najbardziej rozpowszechniony i najbardziej dokuczliwy jest hałas komunikacyjny (GIOŚ, 2013). Jednak osoby będące pod nieustannym wpływem takiego hałasu, często go nie zauważają (Lercher, 1996; Staples, 1996). Przykładem może być odległy szum pojazdów przejeżdżających autostradą. Podobna sytuacja może mieć miejsce w przypadku emiterów hałasu o wysokim natężeniu, ale występujących krótkotrwale i okresowo, na przykład w pobliżu linii kolejowych.

Podstawową jednostką określającą poziom dźwięku jest decybel (dB). Dźwięki o natężeniu poniżej 35 dB są w większości nieszkodliwe dla zdrowia, lecz mogą być denerwujące i dekoncentrujące. Przy dźwiękach 35-70 dB pojawia się zmęczenie układu nerwowego, utrudnione jest rozumienie mowy, zasypianie i odpoczynek. Natężenie dźwięku 75-85 dB prowadzi do zmniejszenia wydajności pracy, mogą pojawić się problemy ze słuchem; a przy 90-130 dB pojawiają się schorzenia narządów wewnętrznych. Hałas powyżej 130 dB trwałe uszkadza słuch i wywołuje drgania narządów wewnętrznych (Engel i Sadowski, 2005). Najbardziej widoczne i najszybciej obserwowane objawy związane z ekspozycją na hałas to zmęczenie, rozdrażnienie, osłabienie koncentracji i zdolności do nauki, zaburzenia orientacji, drażliwość, ból głowy, szumy w uszach. U dzieci może wystąpić niepokój, poczucie zagubienia, płacz (Trybalska i inni, 1997; Pawlas, 2015). M. van den Berg (2005) stwierdził, że zaburzenia pracy układu krążenia, osłabienie słuchu i obniżenie sprawności intelektualnej mogą nastąpić w wyniku długotrwałej ekspozycji na hałas o natężeniu przewyższającym 70 dB (patrz również: Engel i Sadowski, 2005). Subiektywnie odczuwana dokuczliwość i pogorszenie jakości snu ma miejsce przy hałasie rzędu 40-42 dB, lecz źródłem niespokojnego snu może już być hałas w pomieszczeniu, w którym śpimy, o natężeniu 35 dB. Efektem długotrwałego przebywania w środowisku o nadmiernym hałasie może być tzw. zespół pohałasowy obejmujący upośledzenie funkcji fizjologicznych i psychicznych człowieka.

Światowa Organizacja Zdrowia (WHO) jako najczęstsze skutki ekspozycji na hałas wymienia: wahania ciśnienia krwi, nasilenie nadciśnienia tętniczego i choroby niedokrwiennej serca, osłabienie zdolności poznawczych (zwłaszcza u dzieci i młodzieży), zaburzenia snu, zaburzenie i osłabienie słuchu. Podkreśla także znaczną, odczuwaną subiektywnie dokuczliwość hałasu. Ekspozycja na nadmierny hałas może powodować ostry lub przewlekły uraz akustyczny (WHO, 2011). 
W otoczeniu człowieka do najważniejszych antropogenicznych źródeł hałasu należą środki transportu (hałas: drogowy, kolejowy, lotniczy). Inne, powszechnie występujące źródła hałasu środowiskowego to: źródła komunalne (np. sąsiedzi, radio, telewizja, bary, restauracje), źródła społeczne i związane z wypoczynkiem (np. odtwarzacze muzyki, zabawki, otwarte imprezy kulturalne i masowe) oraz urządzenia przemysłowe i prace budowlane. O ile w pewnym zakresie jesteśmy w stanie odizolować się od społecznych i przemysłowych źródeł hałasu, o tyle hałas komunikacyjny, a zwłaszcza hałas drogowy oraz hałas komunalny są powszechne w naszym otoczeniu (Baranowski i inni, 2014; Komornicki i inni, 2015).

Badania ankietowe prowadzone w Warszawie przez Państwowy Zakład Higieny (PHZ) pozwoliły na opracowanie skali subiektywnej uciążliwości hałasu komunikacyjnego (Koszarny i Szata, 1987). Hałas o natężeniu <52 dB jest oceniany jako mało uciążliwy, średnio uciążliwy 52-62 dB. Dużą uciążliwością cechuje się hałas o natężeniu 63-70 dB, a bardzo dużą >70 dB.

Pomiary hałasu na terenie uzdrowisk mają w większości charakter okazjonalny i są wykonywane na etapie starań o uzyskanie statusu uzdrowiska bądź w ramach odnawianego co 10 lat operatu uzdrowiskowego. Bardzo rzadko takie pomiary wykonywane są w ramach prowadzonego przez WIOŚ monitoringu środowiska (od 2019 r. w ramach GIOŚ). Jeśli nawet takie badania były prowadzone, to wykonywano je przy głównych drogach i nie reprezentowały rzeczywistych warunków klimatu akustycznego w miejscach przebywania kuracjuszy.

\section{Przebieg stref ochrony uzdrowiskowej a klimat akustyczny}

Ustawa z 2012 r. (Dz. U. 2012, poz. 1109) określa bardzo rygorystyczne normy natężenia hałasu, jednakowe dla wszystkich uzdrowisk. Nie uwzględnia jednak ich cech środowiskowych, czy funkcji społecznych i gospodarczych jakie pełnią. Takie podejście wydaje się zasadne z punktu widzenia zapewnienia optymalnych warunków do leczenia i rehabilitacji kuracjuszy. Jednak wiele miejscowości uzdrowiskowych realizuje także inne funkcje (Cieślak, 2014). Najczęściej jest to funkcja turystyczna (z uwagi na dużą atrakcyjność zarówno przyrodniczą jak i kulturową). Część miejscowości uzdrowiskowych pełni także funkcję administracyjną (są siedzibami powiatów np. Sopot), a nawet przemysłową (często na terenie strefy " $\mathrm{A}$ " znajdują się rozlewnie wód mineralnych jak chociażby w Busku-Zdroju czy Wysowej). W przypadku takich uzdrowisk trudno jest jednoznacznie określić, które czynniki mają decydujący wpływ na warunki akustyczne.

Dobrym przykładem wielofunkcyjności są uzdrowiska nadmorskie: Świnoujście i Kołobrzeg. Są to znane, duże powierzchniowo uzdrowiska, z wieloma obiektami sanatoryjnymi i z bogatym zapleczem leczniczo-socjalnym. W obu tych miejscowościach strefa " $A$ ” ochrony uzdrowiskowej znajduje się w pasie przymorskim. Należałoby się zatem spodziewać podobnych warunków klimatu akustycznego. Jednak już samo porównanie kształtów stref ochrony uzdrowiskowej wskazuje na inne czynniki warunkujące poziom hałasu. Zgodnie z Ustawą z 2005 r. o lecznictwie uzdrowiskowym (Dz.U. 2017, poz. 1056) na obszarze uzdrowiska wydziela się trzy strefy ochrony uzdrowiska oznaczone literami A, B, C. Idealny kształt strefy "A" powinien być zbliżony do koła, gdzie procentowy udział terenów zielonych wynosi nie mniej niż 65\%. Wewnątrz zlokalizowane są obiekty i urządzenia służące lecznictwu uzdrowiskowemu oraz szeroko rozumianej obsłudze kuracjuszy. Strefa „B" powinna przylegać do strefy A i stanowić jej otoczenie. W strefie tej mogą znajdować się nieuciążliwe obiekty usługowe i turystyczne. W jej skład mogą wchodzić parki narodowe, 
rezerwaty przyrody i jeziora. Procentowy udział terenów biologicznie czynnych powinien wynosić nie mniej niż 50\%. Strefa „C" przylega bezpośrednio do strefy „B" i stanowi jej otoczenie. Procentowy udział terenów zielonych wynosi tu nie mniej niż 45\%. Jest to obszar, którego rolą jest zachowanie walorów krajobrazowych oraz ochrona złóż naturalnych surowców leczniczych. Taki układ stref ma wyeliminować wpływ zagrożeń zewnętrznych na klimat wewnątrz strefy ochrony ścisłej uzdrowiska. W rzeczywistości układ stref bardzo często jest daleki od idealnego.

Celem pracy jest ogólna ocena stanu zagrożenia hałasem w uzdrowiskach polskich i trendu jego zmian w ostatnim dziesięcioleciu. Ponadto wskazane zostaną czynniki stanowiące realne źródło hałasu oraz przykłady efektywnych działań naprawczych na podstawie uzdrowisk nadmorskich w Świnoujściu i Kołobrzegu.

\section{Materiały i metody}

Pomiary poziomu hałasu prowadzono w latach 2007-2009 i 2017-2019 w ramach przygotowywania operatów uzdrowiskowych. Do badań wykorzystano metodę bezpośrednich, kilkudniowych ciągłych pomiarów w ograniczonym czasie (Dz. U. Nr. 140, poz. 842). Łącznie badania przeprowadzono na terenie 35 uzdrowisk, przy czym w 20 pomiary prowadzono w obu okresach badawczych (ryc. 1). Tak więc, przynajmniej jednokrotnie badania prowadzone były na terenie 78\% uzdrowisk polskich, a w 44,5\% przypadków badania odbyły się w dwóch kolejnych okresach wynikających z konieczności odnowienia przez gminy operatów uzdrowiskowych.

Badania obejmowały przede wszystkim strefę „A" ochrony uzdrowiskowej, zarówno przy ciągach komunikacyjnych, jak i w parkach (ryc. 2A), trasach spacerowych i w sąsiedztwie sanatoriów i innych obiektów uzdrowiskowych. Pozwoliło to na określenie klimatu akustycznego całych uzdrowisk, a nie tylko natężenia hałasu komunikacyjnego. W niektórych uzdrowiskach wykonano też pomiary w profilach, w różnej odległości od największego źródła hałasu komunikacyjnego. Pomiarom poziomu hałasu towarzyszył pomiar natężenia ruchu pojazdów mechanicznych z podziałem na kategorie.

Pomiary hałasu wykonywano przy użyciu całkujących mierników poziomu dźwięku SON-50 oraz DSA-50 firmy SONOPAN, usytuowanych na statywach, na wysokości ok. 1,5 lub 4 m nad gruntem, w zależności od rodzaju terenu (ryc. 2B). Prowadzono je w sezonie wegetacyjnym, w okresie ulistnienia drzew i w warunkach atmosferycznych określonych w Rozporządzeniu Ministra Środowiska z dnia 16 czerwca 2011 r. (Dz. U. Nr. 140, poz. 842) i wytycznymi GDDKiA (2005): przy prędkości wiatru poniżej $5 \mathrm{~m} / \mathrm{s}$, w temperaturze powietrza powyżej $-5^{\circ} \mathrm{C}$, wilgotności względnej poniżej $98 \%$ i przy braku opadów atmosferycznych.

Zgodnie z Rozporządzeniem Ministra Środowiska z dnia 1 października 2012 r. (Dz. U. 2012, poz. 1109) wartości dopuszczalnych krótkookresowych poziomów hałasu zostały ustalone, w zależności od funkcji urbanistycznej jaką pełni dany teren. Dla terenów wymagających intensywnej ochrony przed hałasem, jakim są tereny w strefie "A" ochrony uzdrowiskowej, określone są najniższe poziomy dopuszczalne (tab. 1). 




- pomiar hałasu w latach 2007-2009

- pomiar hałasu w latach 2017-2019

- pomiar hałasu w latach 2007-2009 i 2017-2019

- obszary ochrony uzdrowiskowej z jedną serią pomiaru hałasu w latach 2009-2015

- pozostałe uzdrowiska statutowe

Ryc. 1. Uzdrowiska statutowe i obszary ochrony uzdrowiskowej w Polsce (opracowanie graficzne: Agnieszka Halaś)

Statutory health resorts and spa protection areas in Poland (graphic design: Agnieszka Halaś) 


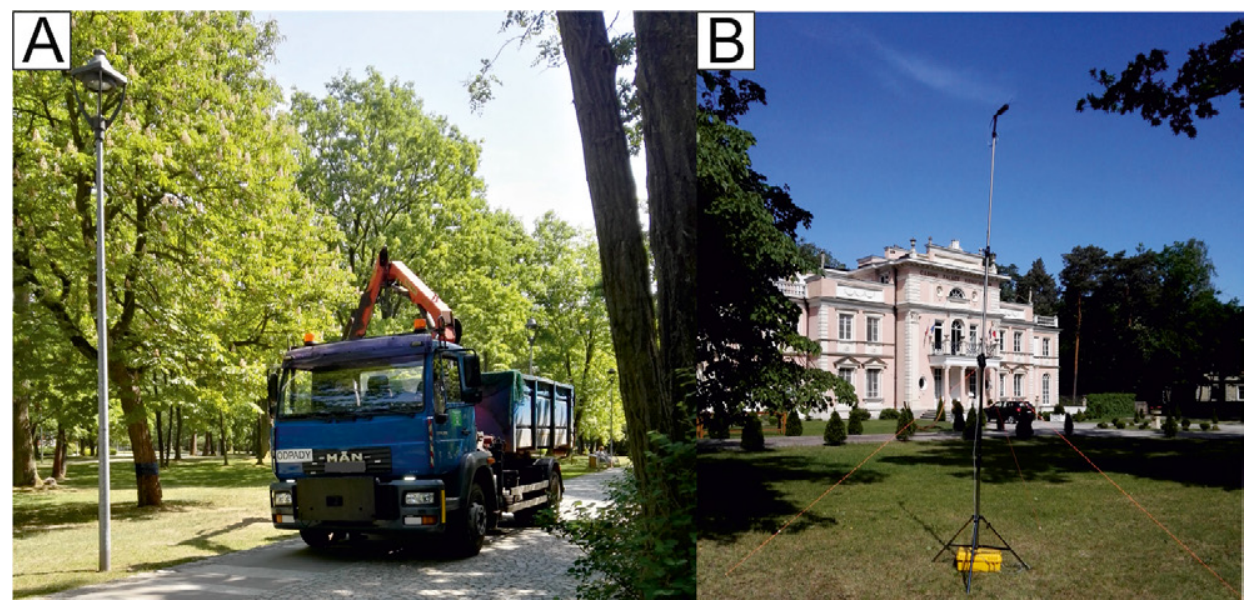

Ryc. 2. A: przykładowe źródło hałasu samochodowego w strefie „A” uzdrowiska; B: stanowisko pomiaru hałasu A: example of a car noise source in zone " $A$ " of a health resort; $B$ : noise measurement station

Tabela 1. Wartości natężenia hałasu dopuszczalne w środowisku Noise limits permissible in the environment

\begin{tabular}{|c|c|c|c|c|}
\hline \multirow{3}{*}{ Rodzaj terenu } & \multicolumn{4}{|c|}{$\begin{array}{c}\text { Dopuszczalny poziom hałasu w [dB] } \\
\text { przedziały czasu odniesienia }\end{array}$} \\
\hline & \multicolumn{2}{|c|}{ Drogi lub linie kolejowe } & \multicolumn{2}{|c|}{$\begin{array}{l}\text { Pozostałe obiekty i działalność będą } \\
\text { ca źródłem hałasu }\end{array}$} \\
\hline & $\begin{array}{l}L_{\text {Aeq } D} \\
16 \text { godzin } \\
\text { w ciągu } \\
\text { dnia }\end{array}$ & $\begin{array}{l}L_{\text {Aeq } N} \\
8 \text { godzin } \\
\text { w nocy }\end{array}$ & $\begin{array}{c}\mathrm{L}_{\text {Aeq D }} \\
8 \text { najmniej korzyst- } \\
\text { nych godzin dnia } \\
\text { kolejno po sobie } \\
\text { następujących }\end{array}$ & $\begin{array}{l}\text { Leq } \mathrm{N} \\
1 \text { najmniej } \\
\text { korzystna } \\
\text { godzina } \\
\text { w nocy }\end{array}$ \\
\hline $\begin{array}{l}\text { Strefa ochronna „A” uzdrowiska } \\
\text { Tereny szpitali poza miastem }\end{array}$ & 50 & 45 & 45 & 40 \\
\hline $\begin{array}{l}\text { Tereny: zabudowy mieszk. jednorodzin- } \\
\text { nej, związanej ze stałym/czasowym po- } \\
\text { bytem dzieci i młodzieży, domów opieki } \\
\text { społecznej, szpitali w miastach }\end{array}$ & 61 & 56 & 50 & 40 \\
\hline $\begin{array}{l}\text { Tereny: zabudowy mieszk. wielorodzin- } \\
\text { nej, zabudowy zagrodowej, rekreacyjno- } \\
\text {-wypoczynkowe, mieszkaniowo-usługowe }\end{array}$ & 65 & 56 & 55 & 45 \\
\hline $\begin{array}{l}\text { Strefa śródmiejska miast } \\
\text { pow. } 100 \text { tys. mieszkańców }\end{array}$ & 68 & 60 & 55 & 45 \\
\hline
\end{tabular}

Źródło: Rozporządzenie Ministra Środowiska (Dz. U. 2012, poz. 1109).

Source: Act of the Ministry of Environment (Dz. U. 2012, poz. 1109).

Podstawowym wskaźnikiem jakości klimatu akustycznego w środowisku jest średni równoważny poziom dźwięku dla pory dnia $\left(\mathrm{L}_{\text {Aeq D }}\right)$ i pory nocy $\left(\mathrm{L}_{\text {Aeq }}\right)$ (Dz. U. Nr. 140, poz. 842). $L_{\text {Aeq. }}$ Jest to skorygowany według krzywej korekcyjnej A poziom ciśnienia akustycznego ciągłego ustalonego dźwięku. Średnią wartość równoważonego poziomu dźwięku w czasie odniesienia T dla pory dnia i pory nocy oblicza się według wzoru: 
gdzie:

$$
L_{\text {Aeq } T}=10 \log \left\lceil\frac{1}{T} \sum_{k=1}^{n} t k 10^{0,1 L_{\text {Aeq } t k}}\right\rceil
$$

$T \quad-$ przedział czasu odniesienia, w sekundach [s],

tk - długość reprezentatywnego przedziału czasu, w sekundach [s],

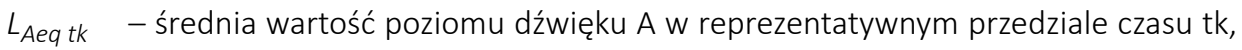
w decybelach $[\mathrm{dB}]$,

$n \quad-$ liczba reprezentatywnych przedziałów czasu tk.

Należy jednak pamiętać, że równoważny poziom dźwięku odnosi się do wszystkich występujących w danym środowisku źródeł dźwięku, zarówno naturalnych (np. szum drzew i wody, śpiew ptaków), jak i antropogenicznych (np. pojazdy, muzyka, maszyny i urządzenia). Dlatego też przy ocenie klimatu akustycznego niezbędne jest określenie źródeł pochodzenia dźwięków występujących w danym terenie, zarówno dominujących jak i pojawiających się sporadycznie.

W ocenie oddziaływania hałasu na przebywającego w uzdrowisku kuracjusza ważne jest określenie czasu, którym jest on narażony na dźwięki o natężeniu przekraczającym wartości graniczne (tab. 1). Czas ten można wyrazić w minutach ekspozycji lub też w odsetku czasu pomiarów (IGIPZ, 2016).

\section{Wyniki i dyskusja}

\section{Ogólna charakterystyka klimatu akustycznego uzdrowisk w Polsce}

W tabeli 2 zestawiono podstawowe informacje o równoważnych poziomach dźwięku w 20 badanych uzdrowiskach. Wybrano dane ze stanowisk o najwyższej i najniższej wartości równoważnego poziomu dźwięku w każdym z okresów badawczych, zarówno dla pory dnia jak i pory nocy, oraz obliczoną średnią obszarową dla całej strefy "A" uzdrowiska. Wartości skrajne pokazują zakres poziomu hałasu w jakim przebywa kuracjusz w uzdrowisku. Aż 90\% „najgłośniejszych” stanowisk z okresu 2007-2008, miało także najmniej korzystny klimat akustyczny w czasie badań prowadzonych 10 lat później. Blisko połowa z nich miała nieco gorsze warunki akustyczne w stosunku do badań wcześniejszych, między innymi: Konstancin-Jeziorna czy Szczawno-Zdrój.

We wszystkich badanych uzdrowiskach w miejscach najbardziej narażonych na nadmierny hałas przekroczone były normy zarówno dla godzin dziennych jak i nocnych. Jednocześnie, w każdym z uzdrowisk znajdowały się obszary względnie ciche, gdzie normy hałasu były zachowane. Średnia obszarowa wartość $L_{\text {Aeq }}$ dla strefy „A" oscyluje w nich wokół $50 \mathrm{~dB}$. Biorąc pod uwagę uzdrowiska, w których badania hałasu prowadzono w obydwu okresach można stwierdzić, że w ponad połowie z nich średnia obszarowa przekraczała wartość normatywną równą 50 dB. Świadczy to o nie najlepszych warunkach klimatu akustycznego w polskich uzdrowiskach oraz o braku wyraźnej poprawy w tym zakresie.

Problem nadmiernego zanieczyszczenia hałasem dotyczy zatem wszystkich uzdrowisk. Nie można jednoznacznie stwierdzić, że $w$ dużych uzdrowiskach nastąpiło pogorszenie warunków akustycznych, a w małych sytuacja się poprawiła. W części badanych uzdrowisk notowano np. zwiększenie wartości równoważnego poziomu dźwięku zarówno w miej- 
Tabela 2. Wybrane charakterystyki poziomu hałasu w badanych uzdrowiskach w latach 2007-2008 oraz 2017-2018 Selected characteristics of noise levels in the examined health resorts in years 2007-2008 and 2017-2018



$\mathrm{x}$ - pomiaru nie prowadzono 
scach najbardziej narażonych na hałas (dotyczy strefy A), jak również notowano tam wyższą wartość średnią dla całego badanego obszaru. Do takich uzdrowisk należą np. Konstancin-Jeziorna czy Polańczyk. W obu przypadkach przyczyną jest nadmierny hałas komunikacyjny. Podejmowane przez władze gmin, czy inwestorów prywatnych działania inwestycyjne, nie zawsze uwzględniają czynniki wpływające na klimat akustyczny danego miejsca, a ich działania koncentrują się niekiedy na aspektach wizualnych, gospodarczych, czy społecznych. Poza tym, w ostatnich latach wyraźnie obserwuje się zwiększenie ruchu pojazdów na polskich drogach (Komornicki i inni, 2015). W niektórych uzdrowiskach, pomimo wzrostu natężenia hałasu w miejscach najgłośniejszych (Duszniki-Zdrój, Jedlina-Zdrój), notowano zmniejszenie średniej wartości obszarowej równoważnego poziomu dźwięku. Taki stan rzeczy wskazuje na zagrożenia hałasem tylko w konkretnych miejscach związanych najczęściej z nadmiernym ruchem samochodowym, bądź atrakcjami przyciągającymi kuracjuszy (główne ciągi komunikacyjne, tereny w pobliżu pijalni wód lub innych obiektów sanatoryjnych, sąsiedztwo restauracji z ogródkami, czy budów prowadzonych w uzdrowiskach).

Zwiększona motywacja władz do działań zmierzających do poprawy warunków akustycznych miała miejsce w uzdrowiskach, w których już wcześniej obserwowano dużą presję społeczną na eliminację zagrożeń związanych z propagacją hałasu (Świnoujście, Kołobrzeg). Miejscowe regulacje prawne ograniczyły np. ruch samochodów na terenie strefy „A $\mathrm{A}$, czy organizowanie głośnych imprez w godzinach nocnych.

\section{Przebieg stref ochrony uzdrowiskowej a klimat akustyczny - studium przypadku}

Teren strefy „A” w uzdrowisku Świnoujście stanowi dosyć zwarty obiekt przestrzenny, jednak przebieg jej granic jest nieco odmienny od idealnego (ryc. 3). Dotyczy to głównie linii brzegowej, gdzie granice wszystkich stref się łączą. Ustawa o lecznictwie uzdrowiskowym z 2017 r. dopuszcza taką sytuację (Dz. U. 2017, poz. 1056, art. 33): „Jeżeli odcinek granicy strefy "A" pokrywa się z brzegiem morskim, to stanowi on na tym odcinku również granicę strefy „B” i „C" obszaru, któremu został nadany status uzdrowiska albo status obszaru ochrony uzdrowiskowej". Z pozostałych stron w mniejszym, bądź większym stopniu strefy okalają strefę „A", stanowiąc jej ochronę. Większość obiektów sanatoryjno-wypoczynkowych znajdujących się w strefie „A" otaczają tereny leśno-parkowe. Od strony wschodniej i południowej graniczą one z terenami, na których prowadzona jest działalność turystyczno-wypoczynkowa i gdzie znajdują się największe źródła zagrożeń hałasem komunalnym i komunikacyjnym.

W przypadku Kołobrzegu obszary strefy ochrony uzdrowiska zostały wpisane w istniejącą już infrastrukturę sanatoryjno-wypoczynkową (ryc. 4). Chcąc zachować określone zapisy ustawy dotyczące powierzchni i rodzaju pokrycia stref, konieczne były pewne „zabiegi techniczne” dotyczące przebiegu granic stref ochrony uzdrowiskowej. Pozwoliło to na zachowanie statusu uzdrowiska, ale wzajemny układ stref A, B i C znacząco odbiega od opisanego w ustawie. Uzdrowisko Kołobrzeg posiada dwie oddzielone od siebie strefy "A": Aw - obszar "A" wschodni o powierzchni 543,75 ha oraz Az - obszar "A" zachodni o powierzchni 83,3 ha. Łącznie strefa „A” zajmuje powierzchnię 627,05 ha. W północnej części uzdrowiska, podobnie jak w Świnoujściu, granice stref biegną brzegiem morza.

O ile strefa "A" stanowi w przybliżeniu dwa prostokąty, to pozostałe strefy mają układ nieregularny. W części wschodniej uzdrowiska jedyny bufor stanowi rozczłonkowana stre- 


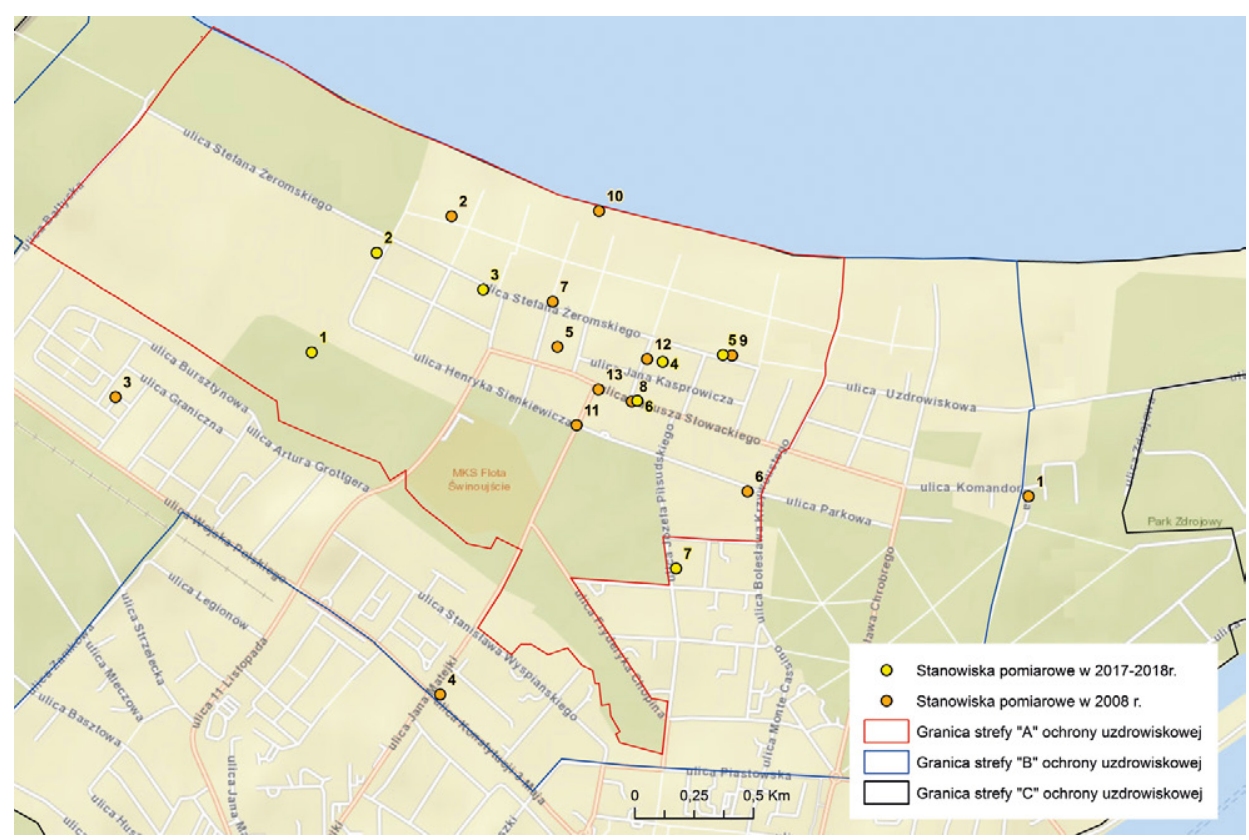

Ryc. 3. Obszar „A” ochrony uzdrowiskowej w Świnoujściu z zaznaczonymi punktami pomiarów hałasu (opracowanie graficzne: Kaja Czarnecka)

Zone " $A$ " of spa protection in Świnoujście with marked-noise measurement points (graphic design: Kaja Czarnecka)

fa „B". Na pewnym odcinku granica strefy „B" pokrywa się z granicą strefy "C". Taka sytuacja nie jest sprzeczna z zapisami wspomnianej ustawy z roku 2017: „W sytuacjach, w których określenie strefy "C" ochrony uzdrowiskowej nie jest możliwe, a nie będzie to miało negatywnego wpływu na właściwości naturalnych surowców leczniczych lub właściwości lecznicze klimatu ani nie będzie stanowiło przeszkody w prowadzeniu lecznictwa uzdrowiskowego granica obszaru, któremu został nadany status uzdrowiska, może częściowo pokrywać się z granicą strefy „B” ochrony uzdrowiskowej”. Z punktu widzenia ochrony przed hałasem, taki układ stref znacząco utrudnia działania zmierzające do zachowania norm klimatu akustycznego w strefie „A $\mathrm{A}^{\prime} \mathrm{z}$ uwagi na możliwość lokowania w jej pobliżu obiektów gastronomicznych, organizację imprez plenerowych czy obecność silnie obciążonych ruchem ciągów komunikacyjnych (drogowych i kolejowych). Istotnym faktem jest to, że w Kołobrzegu brak jest buforu parkowo-leśnego pomiędzy strefami „A" i „B”.

Badania potwierdziły, że w obydwu uzdrowiskach problem hałasu dotyczy głównie okresu wypoczynkowego, kiedy do nadmorskich kurortów zjeżdżają tłumy turystów. Problem ten nie omija również strefy „A” uzdrowisk. Prowadzona w tym okresie działalność rozrywkowa w lokalnych restauracjach, klubach czy dyskotekach jest prawdziwą zmorą wszystkich polskich nadmorskich uzdrowisk. 


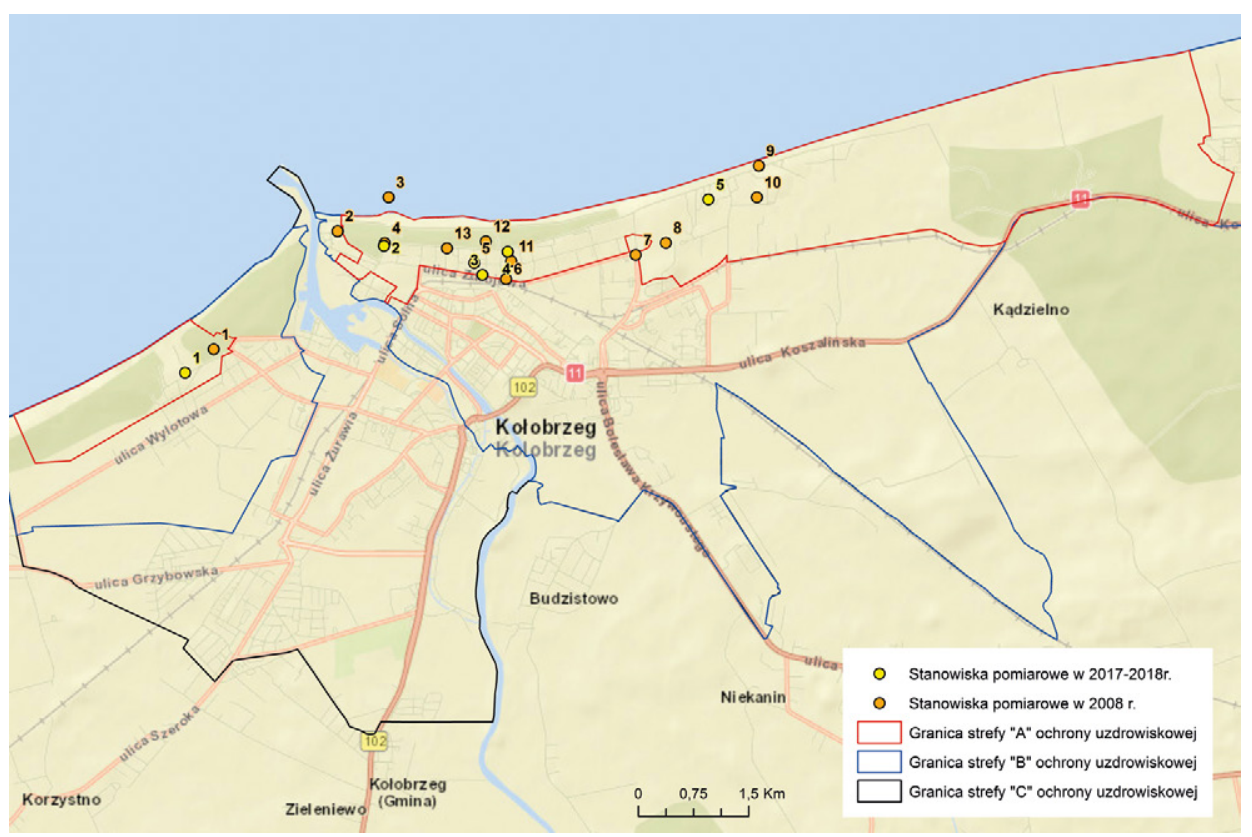

Ryc. 4. Obszar „A" ochrony uzdrowiskowej w Kołobrzegu z zaznaczonymi punktami pomiarów hałasu (opracowanie graficzne: Kaja Czarnecka)

Zone "A" of spa protection in Kołobrzeg with marked noise measurement points (graphic design: Kaja Czarnecka)

\section{Klimat akustyczny Świnoujścia}

Wyniki przeprowadzonych w 2008 r. badań natężenia hałasu (tab. 3) wskazały na przekroczenia norm hałasu w uzdrowisku. Taki stan miał miejsce nawet po wprowadzeniu w 2007 r. przez Radę Miasta uchwały ograniczającej w okresie letniego sezonu turystycznego używania urządzeń nagłaśniających w ogródkach restauracyjnych w godzinach 22:00-10:00. Kolejnymi czynnikami powodującymi zagrożenie komfortu akustycznego był ciągle nasilający się ruch samochodowy w obrębie strefy " $\mathrm{A}^{\prime \prime}$ ochrony uzdrowiskowej i okresowo działająca gastronomia uliczna.

W 2008 r. w Świnoujściu średnia wartość hałasu na terenie strefy „A” ochrony uzdrowiskowej kształtowała się na dosyć wysokim poziomie. Podczas pierwszej serii pomiarowej równoważny poziom dźwięku obliczony dla całego badanego obszaru wynosił 55,8 dB w ciągu dnia i 51,6 dB w najmniej korzystnej porze w nocy. W czasie drugiej serii przeprowadzonej w okresie wzmożonego ruchu turystycznego związanego z majowymi świętami, wartość ta była jeszcze wyższa i wynosiła 58,9 dB w ciągu dnia i aż 64,5 dB w nocy. Istotne jest również to, że średni poziom hałasu przekraczał wartość normatywną prawie na wszystkich punktach pomiarowych z wyjątkiem stanowiska 1 usytuowanego w parku w sąsiedztwie ośrodka akademickiego - Akademii Morskiej przy ul. Komandorskiej (dotyczy to obu serii pomiarowych w ciągu dnia) oraz w rejonie ulic ulokowanych blisko promenady - ul. Żeromskiego i Kasprowicza (w czasie pierwszej nocnej serii pomiarowej), podczas których średni poziom hałasu osiągnął wartość 44 dB (tab. 3, stanowisko 5). 
Tabela 3. Średni równoważny poziom dźwięku LAeq (dB) w Świnoujściu, marzec, maj 2008 Average equivalent sound level LAeq (dB) in Świnoujście, March and May 2008

\begin{tabular}{|c|c|c|c|c|}
\hline \multirow{2}{*}{ Nr stanowiska } & \multicolumn{2}{|c|}{$\mathrm{L}_{\text {Aeq }}[\mathrm{dB}] \mathrm{dzien}$} & \multicolumn{2}{|c|}{$\mathrm{L}_{\text {Aeq }}[\mathrm{dB}] \mathrm{noc}$} \\
\cline { 2 - 5 } & III 2008 & $\mathrm{~V} 2008$ & II 2008 & $\mathrm{~V} 2008$ \\
\hline 1 & 45 & 49 & $\mathrm{x}$ & $\mathrm{x}$ \\
3 & 58 & $\mathrm{x}$ & $\mathrm{x}$ & $\mathrm{x}$ \\
$4^{*}$ & 55 & 54 & 56 & $\mathrm{x}$ \\
5 & 68 & $\mathrm{x}$ & 44 & $\mathrm{x}$ \\
6 & 54 & $\mathrm{x}$ & 60 & $\mathrm{x}$ \\
7 & $\mathrm{x}$ & $\mathrm{x}$ & 45 & 67 \\
8 & $\mathrm{x}$ & $\mathrm{x}$ & $\mathrm{x}$ & $\mathrm{x}$ \\
9 & $\mathrm{x}$ & 64 & $\mathrm{x}$ & $\mathrm{x}$ \\
10 & $\mathrm{x}$ & 56 & $\mathrm{x}$ & 64 \\
11 & $\mathrm{x}$ & $\mathrm{x}$ & $\mathrm{x}$ & 60 \\
12 & $\mathrm{x}$ & $\mathrm{x}$ & $\mathrm{x}$ & 61 \\
\hline 13 & & & & \\
\hline
\end{tabular}

$x$ - pomiaru nie prowadzono

* - punkt pomiarowy poza strefą A

Efektem przeprowadzonych w 2008 r. badań klimatu akustycznego Świnoujścia były zalecenia dla władz miasta dotyczące poprawy warunków akustycznych. Obejmowały one głównie działania zmierzające do:

- weryfikacji i przebudowy wewnętrznego układu komunikacyjnego łącznie z wyłączeniem części ulic w strefie A z ruchu samochodowego (chociażby tylko w okresie szczytu wypoczynkowego),

- ograniczenia emisji akustycznej podstawowych źródeł hałasu, głównie komunikacji samochodowej, a w szczególności samochodów ciężarowych,

- ograniczenia ruchu pojazdów szczególnie uciążliwych,

- wprowadzenie ograniczeń w działalności „rozrywkowej” kawiarni i innych obiektów gastronomicznych, zwłaszcza położonych w sąsiedztwie sanatoriów, a docelowo usunąć te usługi poza strefę „A".

W wyniku odpowiednich decyzji administracyjnych i działań naprawczych władze miasta zrealizowały większość sformułowanych zaleceń. Ich skuteczność zweryfikowano w latach 2017-2018 przeprowadzając na obszarze uzdrowiska Świnoujście ponowne badania klimatu akustycznego (tab. 4). W większości przypadków punkty pomiarów hałasu pokrywały się z tymi z roku 2008. Zaobserwowano mniejsze natężenie dźwięku w najgłośniejszym miejscu (przy ul. Słowackiego - stanowisko 6) o blisko 4 dB zarówno w porze dnia jak i nocy w stosunku do pomiarów z 2008 r. Średnia dla całego uzdrowiska była w tym okresie niższa o $2 \mathrm{~dB}$ dla pory dnia i aż o $10 \mathrm{~dB}$ dla pory nocy.

Korzystnymi rozwiązaniami z punktu widzenia poprawy klimatu akustycznego okazały się: zmiana organizacji ruchu na jednokierunkowy na niektórych ulicach oraz ograniczenia parkowania i ruchu kołowego w niektórych częściach strefy A ochrony uzdrowiskowej. 
Tabela 4. Średni równoważny poziom dźwięku LAeq (dB) w Świnoujściu, czerwiec, sierpień 2017, kwiecień 2018 Average equivalent sound level LAeq (dB) in Świnoujście, June and August 2017, and April 2018

\begin{tabular}{|c|c|c|c|c|c|c|}
\hline \multirow{2}{*}{ Nr stan. } & \multicolumn{3}{|c|}{ LAeq [dB] dzień } & \multicolumn{3}{c|}{ LAeq [dB] noc } \\
\cline { 2 - 7 } & VI 2017 & VIII 2017 & IV 2018 & VI 2017 & VIII 2017 & IV 2018 \\
\hline 1 & 44,7 & 40,6 & $x$ & 33,9 & $x$ & $x$ \\
2 & 51,5 & 55,2 & $x$ & 46,0 & 43,4 & $x$ \\
3 & 51,2 & 53,5 & $x$ & 43,7 & 43,5 & $x$ \\
4 & 49,4 & $x$ & 50,8 & 43,3 & $x$ & 45,0 \\
5 & $x$ & 60,3 & 58,4 & $x$ & 62,7 & 54,3 \\
6 & 59,6 & 56,0 & 56,5 & 51,7 & 47,8 & 56,8 \\
7 & $x$ & $x$ & 50,8 & $x$ & $x$ & 42,7 \\
\hline
\end{tabular}

$\mathrm{x}$ - pomiaru nie prowadzono

W tabeli 5 pokazano jak kształtowało się natężenie ruchu na głównych ciągach komunikacyjnych uzdrowiska podczas badań prowadzonych w 2017 i 2018 r.

Badania natężenia ruchu w uzdrowisku Świnoujście wskazują na znaczący jego udział w strukturze klimatu akustycznego. W rejonie ulic stanowiących centrum lokalnego ruchu kuracjuszy (rejon ulic E. Gierczak i J. Słowackiego) ruch samochodowy jest umiarkowany. Przeciętnie w ciągu dnia w tym miejscu obserwowano 800-1000 pojazdów w ciągu godziny. Znaczącą większość stanowiły samochody osobowe. Najbardziej dokuczliwymi emiterami hałasu były motocykle i quady, choć ich liczba nie była duża to ich przejazdy generowały hałas o największym natężeniu znacząco wpływając na wynikowy, równoważny poziom dźwięku.

Z przeprowadzonych obserwacji wynika, że najbardziej obciążona komunikacyjnie jest północno-wschodnia część strefy „A" w rejonie ulicy, gdzie skupia się ruch samochodowy, pieszy i rowerowy (ul. Żeromskiego - stanowisko 5). Jest ona częścią bardzo uczęszczanego szlaku pieszego i rowerowego prowadzącego z Polski do Niemiec. Równolegle do ulicy biegnie Promenada Nadmorska. Ruch pieszy jest uzależniony od pory roku i warunków pogodowych. W czasie weekendu majowego 2018 r. w porze południowej, na Promenadzie w ciągu godziny spacerowało ponad 2400 osób. W czasie pomiarów wakacyjnych było ich około 900.

Istotnym czynnikiem decydującym o natężeniu hałasu komunikacyjnego jest stan nawierzchni dróg. Uszkodzona nawierzchnia powoduje wtórną emisję hałasu pochodzącego od drgań elementów pojazdów. Na badanym obszarze, w stosunku do pomiarów prowadzonych w 2008 r., zaobserwowano znaczącą poprawę jakości nawierzchni ulic i chodników, co ma bardzo duży wpływ na klimat akustyczny przyległych obszarów. Pośrednio negatywnie mogą wpływać na hałas komunikacyjny te fragmenty ulic, które wykonane są z kostki brukowej. Pojazdy poruszające się po takich nawierzchniach są narażone na dodatkowe drgania i emisję hałasu.

Układ stref ochronnych w uzdrowisku Świnoujście minimalizuje zagrożenie hałasem ze źródeł zewnętrznych. Ważne więc jest zachowanie buforu oddzielającego strefę „ $A$ " od stref "B" i "C", gdzie nie ma tak rygorystycznych ograniczeń dla emiterów hałasu. W Świnoujściu bufor taki, w postaci parku leśnego i parku zdrojowego minimalizuje wpływy zewnętrzne na klimat akustyczny strefy „A". Słabym jego punktem jest jedynie stre- 
Tabela 5. Natężenie ruchu w strefie „A" uzdrowiska Świnoujście w wybranych dniach 2017 i 2018 r. Traffic intensity in zone " $A$ " of Świnoujście health resort on selected days in the years 2017 and 2018

\begin{tabular}{|c|c|c|c|c|c|c|c|}
\hline \multirow{2}{*}{ Data pomiaru } & \multirow{2}{*}{$\begin{array}{c}\text { Nr stano- } \\
\text { wiska }\end{array}$} & \multirow{2}{*}{ Pora doby } & \multicolumn{3}{|c|}{ Pojazdy silnikowe (liczba/godz.) } & \multicolumn{2}{|c|}{ Inni użytkownicy dróg } \\
\hline & & & osobowe & pozostałe * & inne** & rowery & piesi \\
\hline \multirow{12}{*}{$8-9.06 .2017$} & \multirow{4}{*}{ stan. 3} & \multirow{4}{*}{$\begin{array}{l}\text { przedpołudnie } \\
\text { południe } \\
\text { popołudnie } \\
\text { noc }\end{array}$} & 32 & 8 & 8 & 32 & 52 \\
\hline & & & 40 & 12 & 9 & 277 & 192 \\
\hline & & & 36 & 3 & 6 & 245 & 206 \\
\hline & & & 14 & 0 & 0 & 4 & 42 \\
\hline & \multirow{4}{*}{ stan. 4} & \multirow{4}{*}{$\begin{array}{l}\text { przedpołudnie } \\
\text { południe } \\
\text { popołudnie } \\
\text { noc }\end{array}$} & 22 & 8 & 2 & 20 & 72 \\
\hline & & & 54 & 13 & 3 & 224 & $x$ \\
\hline & & & 53 & 5 & 0 & 206 & 133 \\
\hline & & & 35 & 0 & 0 & 21 & 84 \\
\hline & \multirow{4}{*}{ stan. 6} & przedpołudnie & 42 & 15 & 5 & 33 & 148 \\
\hline & & południe & 67 & 25 & 3 & 53 & 320 \\
\hline & & popołudnie & 66 & 17 & 5 & 21 & 111 \\
\hline & & noc & 54 & 3 & 0 & 3 & 63 \\
\hline \multirow{16}{*}{$24-25.08 .2017$} & \multirow{4}{*}{ stan. 2} & przedpołudnie & 11 & 3 & 1 & 5 & 20 \\
\hline & & południe & 58 & 7 & 1 & 28 & 52 \\
\hline & & popołudnie & 58 & 2 & 7 & 28 & 45 \\
\hline & & noc & 14 & 0 & 0 & 2 & 14 \\
\hline & \multirow{4}{*}{ stan. 3} & \multirow{4}{*}{$\begin{array}{l}\text { przedpołudnie } \\
\text { południe } \\
\text { popołudnie } \\
\text { noc } \\
\end{array}$} & 7 & 3 & 1 & 26 & 16 \\
\hline & & & 51 & 6 & 3 & 483 & 234 \\
\hline & & & 38 & 4 & 7 & 389 & 302 \\
\hline & & & 18 & 0 & 0 & 27 & 68 \\
\hline & \multirow{4}{*}{ stan. 5} & \multirow{4}{*}{$\begin{array}{l}\text { przedpołudnie } \\
\text { południe } \\
\text { popołudnie } \\
\text { noc }\end{array}$} & 32 & 3 & 0 & 18 & 900 \\
\hline & & & 161 & 5 & 6 & 324 & 816 \\
\hline & & & 178 & 4 & 4 & 288 & 890 \\
\hline & & & 100 & 2 & 0 & 30 & 462 \\
\hline & \multirow{4}{*}{ stan. 6} & \multirow{4}{*}{$\begin{array}{l}\text { przedpołudnie } \\
\text { południe } \\
\text { popołudnie } \\
\text { noc }\end{array}$} & 38 & 13 & 2 & 37 & 103 \\
\hline & & & 83 & 22 & 4 & 83 & 485 \\
\hline & & & 76 & 18 & 6 & 92 & 556 \\
\hline & & & 132 & 7 & 2 & 20 & 106 \\
\hline \multirow{16}{*}{ 28-29.04.2018 } & \multirow{4}{*}{ stan. 3} & \multirow{4}{*}{$\begin{array}{l}\text { przedpołudnie } \\
\text { południe } \\
\text { popołudnie } \\
\text { noc } \\
\end{array}$} & 12 & 4 & 2 & 17 & 36 \\
\hline & & & 84 & 3 & 7 & 375 & 278 \\
\hline & & & 36 & 1 & 5 & 243 & 178 \\
\hline & & & 15 & 0 & 0 & 15 & 60 \\
\hline & & przedpołudnie & 18 & 3 & 1 & 19 & 95 \\
\hline & & południe & 81 & 8 & 11 & 422 & 2400 \\
\hline & stan. 5 & popołudnie & 82 & 5 & 7 & 201 & 2334 \\
\hline & & noc & 34 & 2 & 0 & 7 & 154 \\
\hline & & przedpołudnie & 21 & 6 & 0 & 6 & 48 \\
\hline & & południe & 47 & 8 & 0 & 38 & 350 \\
\hline & stan. 6 & popołudnie & 68 & 9 & 3 & 47 & 440 \\
\hline & & noc & 60 & 4 & 3 & 6 & 168 \\
\hline & & przedpołudnie & 20 & 2 & 0 & 8 & 53 \\
\hline & & południe & 57 & 9 & 4 & 70 & 604 \\
\hline & stan. 7 & popołudnie & 33 & 6 & 0 & 26 & 222 \\
\hline & & noc & 20 & 0 & 0 & 6 & 58 \\
\hline
\end{tabular}

\footnotetext{
* lekkie samochody ciężarowe (dostawcze), samochody ciężarowe, autobusy
}

** motocykle, traktory 
fa brzegowa. We wschodniej części tej strefy, na przedłużeniu Promenady Nadmorskiej, wkroczyła zabudowa turystyczna i handlowo-usługowa. Prowadzona tam działalność powoduje, że we wschodniej, nadmorskiej części strefy A norma hałasu nie jest zachowana (tab. 4, stanowisko 5).

\section{Klimat akustyczny Kołobrzegu}

Jak wspomniano wcześniej, układ stref ochrony uzdrowiskowej w Kołobrzegu znacznie odbiega od idealnego schematu. Specyfiką strefy „A” w Kołobrzegu jest jej podział na część zachodnią (Az) i wschodnią (Aw). Największym zagrożeniem dla klimatu akustycznego jest bezpośrednie sąsiedztwo dzielnicy uzdrowiskowej i zabudowy miejskiej. W części Aw granica ta na znacznym odcinku przebiega wzdłuż czynnej linii kolejowej.

Na rycinie 4 przedstawiono lokalizację punktów pomiarowych w czasie badań prowadzonych w latach 2008 i 2018. Największe wartości natężenia hałasu w strefie Aw notowano właśnie na stanowiskach, które znajdowały się w sąsiedztwie dworca kolejowego leżącego w strefie Bw. Taki stan miał miejsce zarówno w badaniach z 2008 r. (tab. 6, stanowisko 6) jak i w 2018 r. (tab. 7, stanowisko 3). Równoważny poziom dźwięku osiągnął tam wartość około 63 dB. Również nie bez znaczenia jest sąsiedztwo dużych osiedli mieszkaniowych znajdujących się w strefie Bw, które są emiterem szeroko rozumianego hałasu komunalnego.

Dużym problemem dla utrzymania norm klimatu akustycznego w Kołobrzegu jest połączenie funkcji turystycznej i uzdrowiskowej, a przede wszystkim brak wyraźnego buforu leśno-parkowego oddzielającego strefy "A" oraz „B" i „C". Wewnątrz strefy "A" w miejscach zabudowanych, średni poziom hałasu przekraczał $55 \mathrm{~dB}$. Przyczyną tego był hałas samochodowy w samej strefie „A" oraz na ulicach okalających (np. ul. Zdrojowej czy Kasprowicza). Na podstawie operatu klimatycznego wykonanego przez Instytut Geo-

Tabela 6. Średni równoważny poziom dźwięku LAeq (dB) w Kołobrzegu, kwiecień/maj 2008 r. Average equivalent sound level LAeq (dB) in Kołobrzeg, April/May 2008

\begin{tabular}{|c|c|c|}
\hline \multirow{2}{*}{ Nr stanowiska } & LAeq [dB] dzień & LAeq [dB] noc \\
\cline { 2 - 3 } & IV/V 2008 & IV/V 2008 \\
\hline 1 & 46 & $x$ \\
2 & 58 & 57 \\
3 & 53 & $x$ \\
4 & 61 & $x$ \\
5 & 52 & $x$ \\
6 & 63 & 55 \\
7 & 48 & $x$ \\
8 & 42 & $x$ \\
9 & 58 & 56 \\
10 & 52 & 56 \\
11 & 50 & $x$ \\
12 & $x$ & 48 \\
13 & 58 & $x$ \\
\hline
\end{tabular}

$x$ - pomiaru nie prowadzono 
grafii i Przestrzennego Zagospodarowania PAN (IGiPZ PAN), Minister Zdrowia potwierdził możliwość prowadzenia lecznictwa uzdrowiskowego na obszarze uzdrowiska Kołobrzeg. W decyzji zalecił również ograniczenie emisji akustycznej z komunikacji samochodowej oraz wyłączenia z ruchu samochodowego części ulic znajdujących się w strefie „A" ochrony uzdrowiskowej. Mając to na uwadze władze miasta zdecydowały o wprowadzeniu wyższych opłat za postój pojazdów na obszarze zlokalizowanym w granicach strefy " $A$ " ochrony uzdrowiskowej, jak również wzdłuż całego pasa nadmorskiego.

Czy podjęte przez władze miasta działania okazały się skuteczne zweryfikowano podczas badań wykonanych w latach 2017-2018. Przeprowadzone pomiary natężenia hałasu wskazują, że warunki akustyczne w Kołobrzegu są tylko minimalnie korzystniejsze, jednak nie udało się uzyskać znaczącej poprawy klimatu akustycznego. Nadal na znacznej części strefy "A" (zwłaszcza w części Aw) uzdrowiska normy hałasu są wyraźnie przekraczane. Dotyczy to zarówno pory dnia, jak i pory nocy (tab. 7).

Brak wyraźnego buforu leśno-parkowego oddzielającego dzielnicę uzdrowiskową

Tabela 7. Średni równoważny poziom dźwięku LAeq (dB) w Kołobrzegu, kwiecień 2018 r. Average equivalent sound level LAeq (dB) in Kołobrzeg, April 2018

\begin{tabular}{|c|c|c|}
\hline \multirow{2}{*}{ Nr stanowiska } & LAeq [dB] dzień & LAeq [dB] noc \\
\cline { 2 - 3 } & IV 2018 & IV 2018 \\
\hline 1 & 47,5 & 41,0 \\
2 & 54,8 & 45,3 \\
3 & 62,7 & $x$ \\
4 & 55,5 & 42,8 \\
5 & 49,6 & 40,6 \\
\hline
\end{tabular}

$x$ - pomiaru nie prowadzono

od miasta Kołobrzeg oraz przebiegający wzdłuż południowej granicy strefy Aw ciąg komunikacji drogowej i kolejowej ułatwiają przenikanie hałasu emitowanego w strefach „B" i "C" (ze źródeł komunikacyjnych i komunalnych) do strefy "A" ochrony uzdrowiskowej. Natężenie ruchu pociągów pasażerskich w sezonie letnim jest znaczne i wynosi około 80 w ciągu doby. Natężenie ruchu samochodowego w tym rejonie jest nierównomierne. Najbardziej obciążone ruchem samochodowym były godziny poranne i popołudniowe. W porannym szczycie komunikacyjnym, pomiędzy godziną 07 i 08 notowano tam ponad 380 pojazdów. Znaczącą większość stanowiły samochody osobowe (80-90\% - w zależności od pory doby), udział autobusów i samochodów dostawczych był niewielki.

\section{Podsumowanie}

W świetle przeprowadzonych badań tylko nieliczne uzdrowiska w Polsce można określić jako spełniające normy klimatu akustycznego. Dotyczy to głównie uzdrowisk niewielkich, o małej antropopresji, położonych z dala od dużych ośrodków miejskich, tras komunikacyjnych i atrakcji turystycznych (np. Wapienne czy Wieniec-Zdrój). Dla większości dużych i znanych uzdrowisk, pełniących inne funkcje niż tylko lecznicza, dotrzymanie norm ha- 
łasu dla całej strefy A ochrony uzdrowiskowej jest mało realne, nawet przy restrykcyjnym ograniczeniu ruchu samochodowego. Sam bowiem poziom dźwięków tła (rozmowy kuracjuszy, odgłosy naturalne oraz niezbędna działalność gospodarcza w uzdrowisku) może powodować okresowe przekroczenia norm. Jednakże to głównie presja komunikacyjna i turystyczna stanowią największe zagrożenie dla klimatu akustycznego uzdrowisk.

Przeprowadzone badania są podstawą szczegółowych analiz zmierzających do określenia funkcji, jakie pełnią w dzisiejszych czasach uzdrowiska i wynikających z tego zagrożeń dla ich klimatu akustycznego. Rozszerzenie oferty uzdrowisk prowadzi do przekształcenia ich w obiekty wielofunkcyjne. Większość dzisiejszych uzdrowisk stanowi dużą bazę noclegową dla turystyki (np. Kołobrzeg, Świnoujście, Kudowa-Zdrój). Powiązanie działalności sanatoryjnej i turystycznej wymaga organizowania dużych imprez takich jak kongresy, festiwale czy inne imprezy rozrywkowe. Równolegle z działaniami mającymi na celu prowadzenie lecznictwa uzdrowiskowego, proponowane są komercyjne zabiegi relaksacyjne (SPA). Różnorodność oferty wiąże się ze zwiększoną liczbą osób odwiedzających uzdrowiska i większym natężeniem bodźców akustycznych, co dobrze widać na przykładzie Świnoujścia i Kołobrzegu.

Poprawę warunków klimatu akustycznego można uzyskać poprzez pewne zabiegi prawne (ograniczenia: wjazdu samochodów na wyznaczone tereny, używania głośnych sygnałów, czy koncentrowania obiektów gastronomicznych i hotelowych na obrzeżach strefy „A"). Można również wykorzystać walory przyrodnicze (lasy, parki, zbiorniki wodne) do tworzenia stref wolnych od dźwięków generowanych przez człowieka. Doświadczenia płynące z wieloletnich badań klimatu akustycznego w uzdrowiskach wskazują, że w zdecydowanej większości istnieją miejsca, w których można zorganizować lokalne strefy ciszy. Miejscowe „oazy ciszy” były by miejscem wypoczynku, nie tylko kuracjuszy i turystów, ale także stałych mieszkańców uzdrowisk.

Ryciny i tabele, pod którymi nie zamieszczono źródła, są opracowaniami własnymi autorów artykułu.

\section{Piśmiennictwo}

Augustyńska D., Kaczmarska A., Koton J., 2014, Hałas, http://www.ciop.pl/6466.html (11.04.2019) Babisch W., Ising H., Gallacher J., 2003, Health status as a potential effect modifier of the relation between noise annoyance and incidence of ischaemic heart disease, Occupational and Environmental Medicine, 60, s. 739-745.

Baranowski J., Błażejczyk K., Milewski P., 2014, Klimat akustyczny w otoczeniu wybranych odcinków dróg w Polsce - wstępne wyniki, Prace i Studia Geograficzne, 56, s. 17-36.

Błażejczyk K., Kuchcik M., 2017, Podstawy bioklimatologii uzdrowiskowej, [w:] I. Ponikowska, W. Kochański (red.), Wielka Księga Balneologii, Medycyny Fizykalnej i Uzdrowiskowej, Konstancin-Jeziorna, s. 83-102.

Cieślak A., 2014, Funkcja uzdrowiskowa i dziedzictwo kulturowe, jako katalizatory rozwoju małych miast, Problemy Rozwoju Miast, 11, 3/2014, s. 21-28.

Engel Z., Sadowski J., 2005, Ochrona środowiska przed hałasem w Polsce w świetle przepisów europejskich, Komitet Akustyki Polskiej Akademii Nauk, Warszawa. 
GDDKiA, 2005, Zarzqdzenie Nr 12 Generalnego Dyrektora Dróg Krajowych i Autostrad z dnia 5 maja 2005 r. w sprawie wykonywania pomiarów hałasu przy drogach krajowych w trakcie generalnego pomiaru ruchu.

GIOŚ, 2013, Stan klimatu akustycznego w Polsce w roku 2012, Warszawa.

IGiPZ PAN, 2016, Instrukcja Nr 01/2016 Dyrektora Instytutu Geografii i Przestrzennego Zagospodarowania PAN z dnia 02.01.2016 r. w sprawie zasad prowadzenia pomiarów immisji hałasu na terenie stref A ochrony uzdrowiskowej oraz oceny klimatu akustycznego z punktu widzenia leczenia klimatycznego (maszynopis).

Komornicki T., Wiśniewski R., Baranowski J., Błażejczyk K., Degórski M., Goliszek S., Rosik P., Solon J., Stępniak M., Zawiska I., 2015, Wpływ wybranych korytarzy drogowych na środowisko przyrodnicze i rozwój społeczno-ekonomiczny obszarów przyległych, Prace Geograficzne, 249, Instytut Geografii i Przestrzennego Zagospodarowania PAN, Warszawa.

Koszarny Z., Szata W., 1987, Narażenie ludności Warszawy na hałas uliczny, cz. I i ll, Roczniki PZH, 1-2, Warszawa.

Kuchcik M., Błażejczyk K., Szmyd J., Milewski P., Błażejczyk A., Baranowski J., 2013, Potencjał leczniczy klimatu Polski, Wydawnictwo Akademickie Sedno, Warszawa.

Lercher P., 1996, Environmental noise and health: An integrated research perspective, Environmental International, 22, s. 117-129.

Pawlas K., 2015, Hałas jako czynnik zanieczyszczajacy środowisko - aspekty medyczne, Medycyna Środowiskowa, 18, 4, 49-56.

Rozporzqdzenie Ministra Środowiska z dnia 1 października 2012 r., w sprawie dopuszczalnych hałasów w środowisku, Dz. U. 2012, poz. 1109.

Rozporzqdzenie Ministra Środowiska z dnia 16 czerwca 2011 r. w sprawie wymagań w zakresie prowadzenia pomiarów poziomów substancji lub energii w środowisku przez zarzqdzajqcego drogq, liniq kolejowq, liniq tramwajowq, lotniskiem lub portem, Dz. U. Nr. 140, poz. 842.

Staples S.L., 1996, Human response to environmental noise, American Psychologist, 51, s. 143-150. Trybalska G., Namysłowski G., Morawski K., 1997, Hałas i jego wpływ na człowieka, Audiofonologia, 11, s. 295-301.

Ustawa z dnia 28 lipca 2005 r. o lecznictwie uzdrowiskowym, uzdrowiskach i obszarach ochrony uzdrowiskowej oraz o gminach uzdrowiskowych (Dz. U. 2017, poz. 1056).

van den Berg M., 2005, Influence of low frequency noise on health and well-being, Informal document No. GRB-41-8, Ministry of Environment, The Hague, Netherlands, http://www.unece.org/ trans/doc/2005/wp29grb/TRANS-WP29-GRB-41-inf08e.doc (19.12.2019).

WHO, 2009, Night noise guidelines for Europe, Regional Office for Europe, Copenhagen.

WHO, 2011, Burden of disease from environmental noise. Quantification of healthy life years lost in Europe, Regional Office for Europe, Copenhagen.

\section{Summary}

Silence and a good acoustic climate are important in every environment where human beings live (at home or the place of work, in the streets, on transport, etc.). Special attention needs to be paid to health resorts at which patients come to regenerate their health. However, the acoustic climate of spas is under the great impact of noise generated by local transport, neighbours, bars and restaurants, as well as by other communal sources. According to the legislative Act of the Ministry of Environment (the Dziennik 
Ustaw Official Journal of Laws of 2012, item 1109) in the core area of a health resort (the so-called zone A), the level of noise level cannot exceed $45 \mathrm{~dB}$ during daytime and $40 \mathrm{~dB}$ during night hours. In places close to roads the limits are slightly higher, at 50 and $45 \mathrm{~dB}$ respectively. These limits are very restrictive. However, we must remember that noise is very destructive and can involve many health disturbances; and health resorts are places in which sick and aged people come to improve their health status and to regenerate organisms.

In spite of the great importance of an appropriate acoustic climate noise measurements are undertaken periodically and not monitored by public institutions. Acoustic climate studies are usually carried out by research institutes (e.g. the Institute of Geography and Spatial Organization of the Polish Academy of Sciences) every ten years, as a part of investigations to assess the quality of climatic conditions in health resorts.

The aim of the paper is a general assessment of the acoustic climate in Polish health resorts and of trends as regards possible changes over the last 10 years (2009-2019) in 20 spas located in different bioclimatic regions of Poland. More detailed analysis is done for 2 coastal resorts (Świnoujście and Kołobrzeg). There are analysed factors influencing the acoustic climate and the effectiveness of actions undertaken by local authorities to reduce noise levels. Attention is paid to the spatial distribution of resort objects (sanatoria, hospitals etc.), the organisation of local transport, and the quality of roads and of the neighbourhood of cities in which tourist and administrative functions are pursued. As the most important factors influencing the acoustic climate are transport and activity of a multifunctional nature (with health-resort and tourist functions having contrasting expectations). 
